\begin{tabular}{|l|l|l|}
\hline \multicolumn{2}{|c|}{ PublisherInfo } \\
\hline \hline PublisherName & $:$ & BioMed Central \\
\hline \hline PublisherLocation & $:$ & London \\
\hline \hline PublisherImprintName & $:$ & BioMed Central \\
\hline \hline
\end{tabular}

\title{
Of mice and men: airway hyperreactivity requires CD40L but not
} $\operatorname{IgE}$

\begin{tabular}{|l|l|l||}
\hline \multicolumn{2}{|c|}{ ArticleInfo } \\
\hline \hline ArticleID & $:$ & 1629 \\
\hline \hline ArticleDOI & $:$ & $10.1186 /$ rr-2001-68561 \\
\hline \hline ArticleCitationID & $:$ & 68561 \\
\hline \hline ArticleSequenceNumber & $:$ & 40 \\
\hline \hline ArticleCategory & $:$ & Paper Report \\
\hline \hline ArticleFirstPage & $:$ & 1 \\
\hline \hline ArticleLastPage & $:$ & 4 \\
\hline \hline & & RegistrationDate : 2001-9-19 \\
ArticleHistory & $:$ & Received \\
& & OnlineDate $\quad: \quad 2001-9-19$ \\
\hline \hline ArticleCopyright & $:$ & Biomed Central Ltd2001 \\
\hline \hline ArticleGrants & $:$ & \\
\hline \hline ArticleContext & $:$ & 129312211 \\
\hline \hline
\end{tabular}


Chritopher O'Brien, ${ }^{\text {Aff1 }}$

Corresponding Affiliation: Aff1

Aff1 University of Pennsylvania, PA, USA

Keywords

Asthma, CD40, CD40L, eosinophilia, IgE

\section{Context}

Asthma is characterized by IgE production, eosinophilic infiltration of the respiratory mucosa, and brochial hyperresponsiveness. A key component of this process is isotype switching and production of IgE in B cells that requires CD40/CD40Ligand (CD40L) interaction between activated T cells and B cells as well as signals provided by interleukin (IL)-4 and IL-13. The specific aim of this study was to address the hypothesis that CD40-CD40L interactions are important in the pathogenesis of asthma. The association of allergic asthma, as well as allergic rhinitis, with elevated $\operatorname{IgE}$ and inflammation has prompted development of therapeutic modalities that directly modulate levels of IgE. Interestingly, such strategies have met with only modest improvement in objective parameters of asthma severity despite impressive reductions in IgE. The findings of this study shed some light on these equivocal therapeutic results.

\section{Significant findings}

The authors found that, unlike wild-type controls, both $C D 40^{-/-}$and $C D 40^{-/-}$mice manifest markedly diminished IgE levels at baseline and following antigen exposure. Surprisingly, bronchopulmonary eosinophilia and inflammation are not altered by the absence of CD40 or CD40L. Unsensitized CD40 ${ }^{-/-}$ mice manifest decreased airway responsiveness when treated with intravenous methacholine. Following antigen sensitization, however, $C D 40^{-/-}$mice show no reduction in airway responsiveness compared to wild-type. Conversely, antigen sensitized $C D 40^{-/-}$mice demonstrate marked reduction in airway hyperreactivity to methacholine compared to wild-type, but manifest a less pronounced decrease in responsiveness prior to antigen sensitization. 
The authors conclude that both CD40 and CD40L are necessary for the generation of an IgE response, but are not required for the generation of pulmonary eosinophilia or inflammatory response to inhaled antigen. CD40L, but not CD40, is required for the development of airway hyperresponsiveness following antigenic stimulation. Conversely, CD40 appears to enhance airway responsiveness in the absence of antigenic stimulation. Finally, the authors conclude that neither elevated IgE nor eosinophilic airway influx are necessary for the development of enhanced airway reactivity following antigenic stimulation. These findings suggest that these two related molecules (CD40 and CD40L) have different roles in the development of asthma and similarly support an IgE-independent parallel pathway leading from antigenic stimulation to the development of airway hyperreactivity that requires CD40L, but not CD40.

\section{Comments}

The association of allergic asthma, as well as allergic rhinitis, with elevated IgE and inflammation has prompted the development of therapeutic modalities that directly modulate levels of IgE. Interestingly, such strategies have met with only modest improvement in objective parameters of asthma severity despite impressive reductions in IgE. The findings of this study reveal the presence of an IgEindependent pathway that mediates the asthma phenotype induced by antigen exposure and consequently sheds some light on these equivocal therapeutic results.

\section{Methods}

Murine model of Aspergillus fumigatus -induced asthma; bronchoalveolar lavage fluid; cytology cell counts, pulmonary histology and bronchial hyperresponsiveness (conductance) were assessed.

\section{Additional information}




\section{References}

1. Mehlhop PD, van de Rijn M, Brewer JP, Kisselgof AB, Geha RS, Oettgen HC, Martin TR: CD40L, but not CD40, is required for allergen-induced bronchial hyperresponsiveness in mice. Am J Respir Cell Mol Biol 2000, 23:646-651. 2000, 23: 646-651.

This PDF file was created after publication. 